\title{
Evaluation of Groundnut Genotypes for Nutritional and Yield Traits
}

\author{
K. John*, P. Prasanthi and P. Latha \\ Regional Agricultural Research Station, Tirupati-517502, India \\ *Corresponding author
}

\section{A B S T R A C T}

Keywords

Variability,

heritability, genetic advance, genetic advance as per cent of mean, groundnut

Article Info

Accepted:

20 May 2021

Available Online:

10 June 2021
The present investigation was undertaken to study the variability, heritability and genetic advance as per cent of mean for nutritional and yield attributes in groundnut genotypes. The estimates of high values of GCV, PCV, heritability and GAM were observed for plant height and moderate values GCV, high heritability and high GAM were recorded for number of immature pods per plant, number of mature pods per plant, dry haulms yield per plant, kernel yield per plant and pod yield per plant. Heritability (broad sense) values ranged from $15.49 \%$ (stem rot incidence) to $96.17 \%$ (plant height). High heritability and along with high GAM were recorded for plant height, number of secondary branches per plant, number of immature pods per plant, number of mature pods per plant, 100 pod weight, dry haulms yield per plant, stem rot incidence, sucrose, kernel yield per plant and pod yield per plant. The results clearly suggested that the involvement of additive gene action for governing of these characters and would be more useful in predicating the resultant effects of selection.

\section{Introduction}

Groundnut is a highly self pollinated crop and can be grown successfully in tropical and sub tropical areas. It is an important oil seed crop of the India. Though it leads in area and production in the world its productivity is low as compared to other countries. Genetic variability is the basic requirement for crop improvement as this provides wider scope for selection. Thus effectiveness of selection is dependent upon the nature, extent and magnitude of genetic variability present in material and the extent to which it is heritable. Hence in the present investigation an attempt was made to investigate the extent of genetic variability and selection parameters like viz., heritability in broad sense and genetic advance for nutritional and yield traits in groundnut. This study will facilitate in understanding 
behind the expression of characters and also the role of environment therein.

\section{Materials and Methods}

The experimental material consisted of thirty five genotypes types of groundnut. The experiment was laid out in randomised block design with four replications at Regional Agricultural Research Station, Tirupati, Andhra Pradesh. Each entry was accommodated in five rows, $5 \mathrm{~m}$ length with spacing of $22.5 \times 10 \mathrm{~cm}$. All the recommended packages of practices were followed to raise a good crop. The observations were recorded in five randomly selected plants, in each entry per replication for nineteen characters viz., days to $50 \%$ flowering, number of primary branches per plant, number of secondary branches per plant, plant height $(\mathrm{cm})$, number of matured pods per plant, number of immature pods per plant, 100 pod weight (g), Shelling per cent, dry haulms yield per plant (g), stem rot incidence (\%), total Free amino acids (ug/g), total carbohydrates (g/g), sucrose (g $\left.100 \mathrm{~g}^{-1}\right)$, protein $(\%)$ and oil $(\%)$, kernel yield per plant $(\mathrm{g})$ and pod yield per plant $(\mathrm{g})$ and mean values were used for statistical analysis. Phenotypic coefficient of variation (PCV), genotypic coefficient of variation (GCV) was estimated as per the formula suggested by Burton (1952). While heritability in broad sense and expected genetic advance were calculated by using the formula given by Allard (1960).

\section{Results and Discussion}

The estimates of genotypic and phenotypic coefficients of variability indicated that the values of phenotypic coefficient of variability (PCV) were always higher than genotypic coefficient of variation (GCV) suggesting the influence of environmental factors. Less difference observed between PCV and GCV in certain cases indicated that these characters were less influenced by the environment. Similar results were reported by Ladole et al., (2009) and Shinde et al., (2011).

In the present investigation, plant height exhibited high GCV and number of secondary branches per plant, number of immature pods per plant, number of mature pods per plant, dry haulms yield per plant $(\mathrm{g})$, stem rot incidence, kernel yield per plant and pod yield per plant showed moderate GCV (Table 1). High magnitude of PCV recorded for plant height, secondary branches per plant, number of immature pods per plant and stem rot incidence and moderate values exhibited for primary branches per plant, number of mature pods per plant, dry haulms yield/plant, kernel yield per plant and pod yield per plant. Plant height recorded high value of GCV and PCV. Moderate values of $\mathrm{GCV}$ and high PCV recorded for secondary branches per plant, number of immature pods per plant and stem rod incidence. Earlier Ladole et al., (2009) observed both GCV and PCV of high magnitude for plant height in groundnut. The genotypic coefficient of variation and phenotypic coefficient of variation were moderate for number of primary branches per plant, number of mature pods per plant, dry haulms yield, total free amino acids, total carbohydrates, sucrose, kernel yield and pod yield. The present findings are in accordance with the findings of Meta (2007).

Genotypic coefficient of variation measures the amount of variation present in a particular character. However, it does not determine the proportion of heritable variation present in the total variation.

Therefore, heritability which represents the heritable variation existing in the character was calculated. High value of heritability and low genetic advance as percentage of mean suggested that their character was conditioned by high genotype environmental interaction. 
Table.1 Genotypic and phenotypic coefficients of variation, heritability (broad sense), genetic advance and genetic advance expressed as per cent of mean for nutritional and yield traits in groundnut.

\begin{tabular}{|c|c|c|c|c|c|c|c|c|}
\hline \multirow[t]{2}{*}{ S. No. } & \multirow[t]{2}{*}{ Character } & \multicolumn{2}{|c|}{ Variance } & \multicolumn{2}{|c|}{ Coefficient of Variance } & \multirow{2}{*}{$\begin{array}{c}\text { Heritability } \\
\text { in broad } \\
\text { sense }(\%)\end{array}$} & \multirow{2}{*}{$\begin{array}{l}\text { Geneti } \\
\text { c } \\
\text { advanc } \\
\text { e }\end{array}$} & \multirow{2}{*}{$\begin{array}{c}\text { Genetic } \\
\text { advance as } \\
\text { per cent of } \\
\text { mean }\end{array}$} \\
\hline & & Genotypic & $\begin{array}{c}\text { Phenotypi } \\
\text { c }\end{array}$ & $\begin{array}{c}\text { Genotypic } \\
(\%)\end{array}$ & $\begin{array}{c}\text { Phenotypic } \\
(\%)\end{array}$ & & & \\
\hline 1 & Days to $50 \%$ flowering & 2.59 & 2.94 & 5.40 & 5.75 & 80.10 & 3.11 & 10.43 \\
\hline 2 & Plant height $(\mathrm{cm})$ & 226.06 & 235.01 & 64.04 & 65.29 & 96.17 & 30.37 & 129.35 \\
\hline 3 & $\begin{array}{l}\text { Number of primary branches } \\
\text { per plant }\end{array}$ & 0.34 & 1.23 & 12.84 & 24.41 & 27.64 & 0.63 & 13.88 \\
\hline 4 & $\begin{array}{l}\text { Number of secondary } \\
\text { branches per plant }\end{array}$ & 0.36 & 1.13 & 29.47 & 52.21 & 31.86 & 0.70 & 34.17 \\
\hline 5 & $\begin{array}{l}\text { Number of mature pods per } \\
\text { plant }(\mathrm{g})\end{array}$ & 18.74 & 31.05 & 30.67 & 39.48 & 60.35 & 6.93 & 49.07 \\
\hline 6 & $\begin{array}{l}\text { Number of immature pods } \\
\text { per plant }\end{array}$ & 6.67 & 10.70 & 49.26 & 62.39 & 62.34 & 4.20 & 80.12 \\
\hline 7 & 100 pod weight $(\mathrm{g})$ & 210.24 & 295.03 & 16.35 & 19.36 & 71.26 & 25.21 & 28.43 \\
\hline 8 & Shelling per cent & 9.07 & 29.57 & 4.44 & 8.01 & 30.67 & 3.44 & 5.06 \\
\hline 9 & 100 kernel weight $(\mathrm{g})$ & 24.87 & 49.85 & 12.52 & 17.76 & 49.89 & 7.26 & 18.22 \\
\hline 10 & $\begin{array}{c}\text { Sound mature kern el per } \\
\text { cent }\end{array}$ & 18.44 & 92.99 & 5.26 & 11.80 & 19.84 & 3.93 & 4.81 \\
\hline 11 & Stem rot incidence $(\%)$ & 24.55 & 158.50 & 38.95 & 98.97 & 15.49 & 4.02 & 31.58 \\
\hline 12 & $\begin{array}{c}\text { Dry haulms yield per plant } \\
(\mathrm{g})\end{array}$ & 15.97 & 19.15 & 32.85 & 35.97 & 83.39 & 7.52 & 61.80 \\
\hline 13 & Total Free amino acids (ug/g) & 3.41 & 7.89 & 28.56 & 34.23 & 42.61 & 2.19 & 9.65 \\
\hline 14 & Total carbohydrates (g/g) & 3.42 & 7.32 & 20.45 & 27.12 & 44.11 & 1.09 & 5.47 \\
\hline 15 & Sucrose $\left({\left.\mathrm{g} 100 \mathrm{~g}^{-1}\right)}^{-1}\right.$ & 3.06 & 4.28 & 23.19 & 31.01 & 85.22 & 3.31 & 120.50 \\
\hline 16 & Protein $(\%)$ & 0.32 & 045 & 1.98 & 2.45 & 62.40 & 0.78 & 3.28 \\
\hline 17 & Oil $(\%)$ & 0.31 & 0.42 & 1.17 & 1.36 & 74.32 & 0.99 & 2.08 \\
\hline 18 & Kernel yield per plant (g) & 5.35 & 7.02 & 28.30 & 32.42 & 76.21 & 4.02 & 49.17 \\
\hline 19 & Pod yield per plant (g) & 11.22 & 13.85 & 27.85 & 30.94 & 81.01 & 6.21 & 51.63 \\
\hline
\end{tabular}


Fig.1

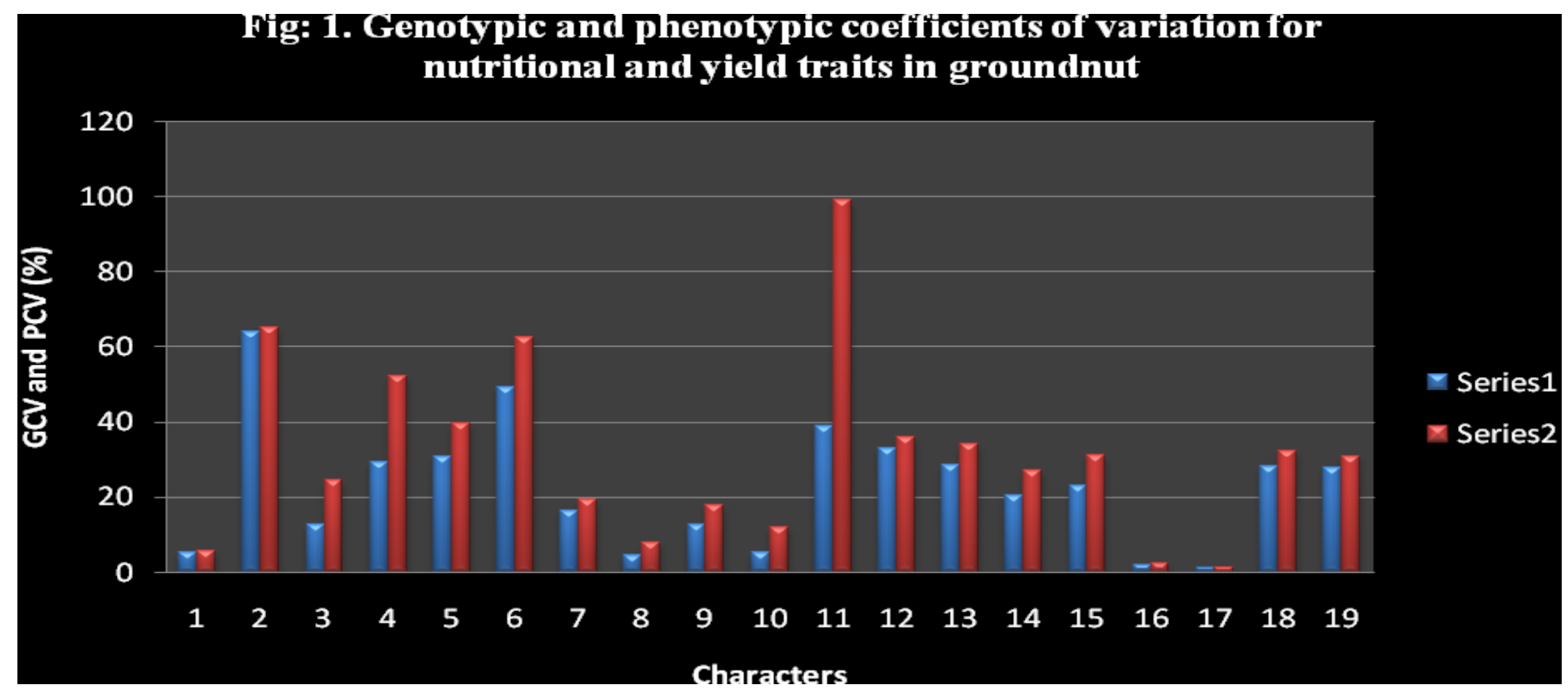

Series 1: GCV (\%) Series 2: PCV (\%)

\begin{tabular}{|c|l|l|l|}
\hline $\mathbf{1}$ & Days to 50 \% flowering & $\mathbf{1 1}$ & Stem rot incidence (\%) \\
\hline $\mathbf{2}$ & Plant height $(\mathrm{cm})$ & 12 & Dry haulms yield per plant $(\mathrm{g})$ \\
\hline $\mathbf{3}$ & Number of primary branches per plant & 13 & Total Free amino acids $(\mathrm{ug} / \mathrm{g})$ \\
\hline $\mathbf{4}$ & Number of secondary branches per plant & 14 & Total carbohydrates $(\mathrm{g} / \mathrm{g})$ \\
\hline $\mathbf{5}$ & Number of mature pods per plant $(\mathrm{g})$ & 15 & Sucrose $\left(\mathrm{g} 100 \mathrm{~g}^{-1}\right)$ \\
\hline $\mathbf{6}$ & Number of immature pods per plant & 16 & Protein $(\%)$ \\
\hline $\mathbf{7}$ & 100 pod weight $(\mathrm{g})$ & 17 & Oil $(\%)$ \\
\hline $\mathbf{8}$ & Shelling per cent & 18 & Kernel yield per plant $(\mathrm{g})$ \\
\hline $\mathbf{9}$ & 100 kernel weight $(\mathrm{g})$ & 19 & Pod yield per plant $(\mathrm{g})$ \\
\hline $\mathbf{1 0}$ & Sound mature kern el per cent & & \\
\hline
\end{tabular}


Fig.2

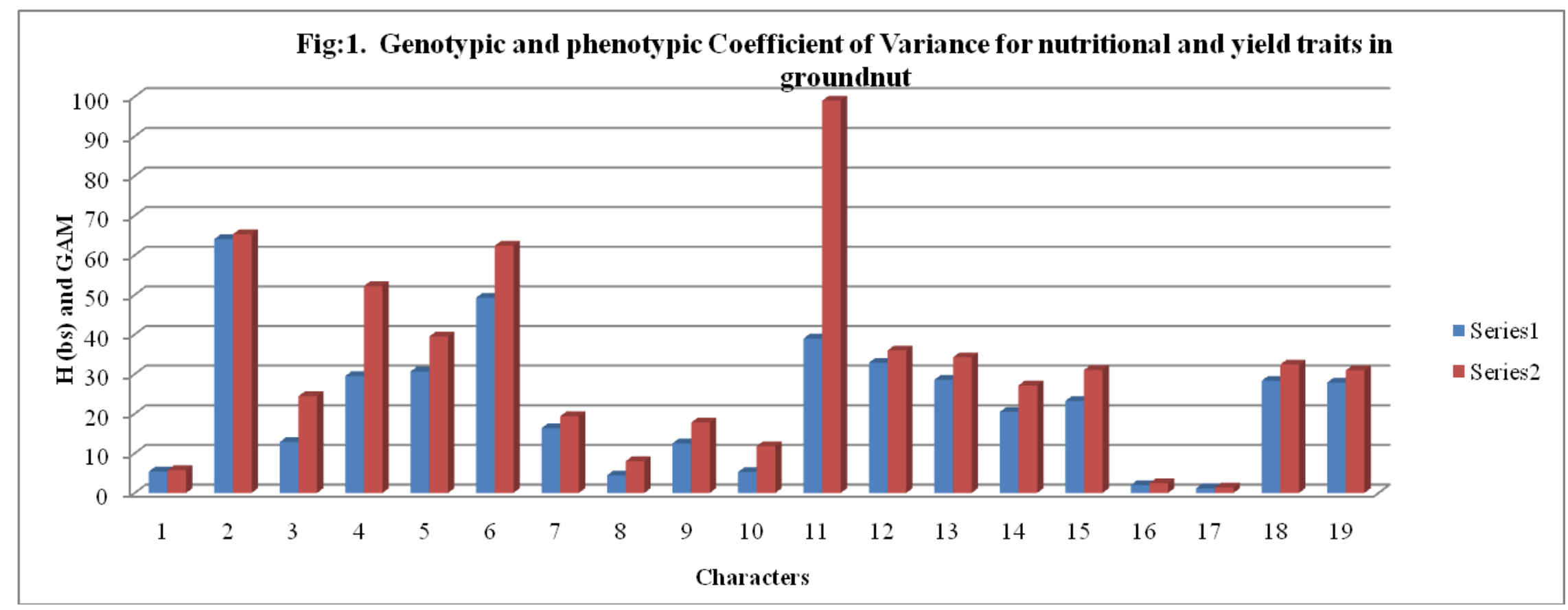

Series 1: $\mathrm{H}_{\mathrm{bs}}(\%)$ Series 2: GAM (\%)

\begin{tabular}{|c|l|l|l|}
\hline $\mathbf{1}$ & Days to 50 \% flowering & $\mathbf{1 1}$ & Stem rot incidence (\%) \\
\hline $\mathbf{2}$ & Plant height $(\mathrm{cm})$ & 12 & Dry haulms yield per plant $(\mathrm{g})$ \\
\hline $\mathbf{3}$ & Number of primary branches per plant & 13 & Total Free amino acids $(\mathrm{ug} / \mathrm{g})$ \\
\hline $\mathbf{4}$ & Number of secondary branches per plant & 14 & Total carbohydrates $(\mathrm{g} / \mathrm{g})$ \\
\hline $\mathbf{5}$ & Number of mature pods per plant $(\mathrm{g})$ & 15 & Sucrose $\left(\mathrm{g} 100 \mathrm{~g}^{-1}\right)$ \\
\hline $\mathbf{6}$ & Number of immature pods per plant & 16 & Protein $(\%)$ \\
\hline $\mathbf{7}$ & 100 pod weight $(\mathrm{g})$ & 17 & Oil $(\%)$ \\
\hline $\mathbf{8}$ & Shelling per cent & 18 & Kernel yield per plant $(\mathrm{g})$ \\
\hline $\mathbf{9}$ & 100 kernel weight $(\mathrm{g})$ & 19 & Pod yield per plant $(\mathrm{g})$ \\
\hline $\mathbf{1 0}$ & Sound mature kern el per cent & & \\
\hline
\end{tabular}


In such situation, selection would not be rewarding. These findings are in accordance with results obtained by Meta (2007).

High heritability values were recorded for days to $50 \%$ flowering, plant height, number of immature pods per plant, number of mature pods per plant, 100 pod weight, dry haulms yield per plant, sucrose, protein, oil content, kernel yield per plant and pod yield per plant. Moderate heritability values recorded for number of secondary branches per plant, shelling per cent and 100 kernel weight. High Genetic advance as percent of mean (GAM) was exhibited for plant height, number of secondary branches per plant, number of immature pods per plant, number of mature pods per plant, 100 pod weight, dry haulms yield per plant, stem rot incidence, sucrose, kernel yield per plant and pod yield per plant and moderate genetic advance as percent of mean for days to $50 \%$ flowering.

The estimate of genetic parameters revealed that shelling per cent, 100 kernel weight, total free amino acids and total carbohydrates expressed moderate heritability and low genetic advance, which in turn indicate the role of non-fixable genetic variance in the expression of these traits. Moderate heritability along with low genetic advance and GCV were observed in the present study for shelling per cent and 100 kernel weight indicated that these characters were largely under the control of non-additive gene action and selection for these traits would be ineffective. The low values of heritability as well as genetic advance were observed for number of primary branches per plant and sound mature kernel percent. Earlier Shinde et al., (2010) reported similar results in groundnut for number of primary branches per plant.

High heritability along with high GAM were observed for plant height, number of immature pods per plant, number of mature pods per plant, 100 pod weight, dry haulms yield per plant, sucrose, kernel yield per plant and pod yield per plant. These results were continued with findings of Naazar et al., (2000) and_Nath et al., (2002). The highly heritable characters with high GAM could be further impressed through individual plant selection. Moderate heritability and high GAM were recorded for number of primary branches per plant.

In the present study, the estimates of high values of GCV, PCV, heritability and GAM were observed for plant height and moderate values GCV, high heritability and high GAM were recorded for number of immature pods per plant, number of mature pods per plant, dry haulms yield per plant, kernel yield per plant and pod yield per plant. The results clearly suggested that the involvement of additive gene action for governing of these characters and would be more useful in predicating the resultant effects of selection. Similar results were reported by Shinde et al., (2010) and John et al., (2006). Thus, from the present investigation, it can be concluded that high genetic advance was not always associated with high heritability for the character studied. Thus, results suggested that the chances for improvement in number of mature pods, haulms yield, sucrose, kernel yield and pod yield would be fairly high as magnitude of heritability and genetic advance as percentage of mean for these characters indicated the presence of wide spectrum of genetic variation suggesting that they merit maximum emphasis in selection for improvement of pod yield in Spanish bunch groundnut.

\section{References}

Allard, R. W. (1960). Principles of Plant breeding. John Wiley and Sons Inc. New York.pp.75-98.

Burton, G. W. (1952). Quantitative inheritance 
in grass. Proceedings of sixth international grassland congress. 1: 227-283.

John, K., Vasanthi, R. P. and Venkateswarlu, O. (2006). Variability and heritability studies in groundnut (Arachis hypogaea L.). Legume Res., 29: 225227.

Kadam, P. S., Desai, D. T., Jagdish., U., Chauhan, D. A. and Shelke, B. L. (2007). Variability, heritability and genetic advance in groundnut. $J$. Maharashtra Agric. Univ., 32(1):7173.

Khote, A. C., Bendale, V. W., Bhave, S. G. and Patil, P. P. (2009). Genetic variability, heritability and genetic advance in exotic genotypes of groundnut (Arachis hypogaea L.). Crop Res., 37 (1, 2 \& 3): 186-191.

Ladole, M. Y., Wakode, M. M. and Deshmukh, S. N. (2009). Genetic variability and characters association studies for yield and yield contributing traits in Groundnut (Arachis hypogaea L) J. Oilseeds. Res., 26 (special issue): $123-125$

Meta, H. R. (2007). Genetic variability, correlation and path coefficient analysis in bunch groundnut (Arachis hypogaea L) Unpublished MSc (Ag) thesis submitted to the Junagadh Agricultural university, Junagadh.

Naazar, A., Mallik, S. N., Bashir, K. and Mirza, M. Y. (2000). Genetic variability, heritability and correlation studies in groundnut. J. Agri., 16: 533536.

Nath, U. K. and Alam, M. S. (2002). On Line Journal of Bio. Sci., 2(11):762-764.

Shinde, P. P., Khanpara, M. D., Vachhani, J. H., Jivani L. L. and Kacchadia, V. H. (2010). Genetic variability in Virginia bunch groundnut (Arachis hypogaea L). Plant Archives. 10(2):703-706.

\section{How to cite this article:}

John, K., P. Prasanthi and Latha, P. 2021. Evaluation of Groundnut Genotypes for Nutritional and Yield Traits. Int.J.Curr.Microbiol.App.Sci. 10(06): 613-619.

doi: https://doi.org/10.20546/ijcmas.2021.1006.067 